\title{
ANALISIS DAMPAK COVID 19 TERHADAP KINERJA KEUANGAN PERBANKAN SYARIAH DI INDONESIA
}

\author{
Ilhami $^{1}$ \& Husni Thamrin ${ }^{2}$ \\ ${ }^{1 \& 2}$ Program Studi Ekonomi Syariah, Pascasarjana UIN Suska Riau \\ Email: ilhamibkn@gmail.com, husni2017husni@gmail.com
}

\begin{abstract}
ABSTRAK
Perbankan syariah di Indoneisa menghadapi sejumlah tantangan di tengah wabah Covid-19. Di masa pandemi Covid 19 saat ini, Perbankan syariah akan menghadapi beberapa kemungkinan resiko terhadap kinerja keuangan. Untuk itu perlu di lakukan Penelitian untuk menganalisis dampak Covid19 terhadap kinerja keuangan Perbankan Syariah dengan melakukan analisa Laporan Keuangan menggunakan rasio keuangan yaitu rasio Return On Asset (ROA), Capital Adequacy Ratio (CAR), Non Performing Finance (NPF) dan Financing Deposit to Ratio (FDR). Penelitian ini adalah penelitian kuantitatif dengan pendekatan deskriptif. Data yang diambil adalah 6 Bulan (September 2019-Februari 2020) sebelum dan 6 Bulan (April 2020-September 2020) setelah diumumkannya kasus pertama Covid-19 yaitu pada 2 Maret 2020. Data diolah dengan paired sample t-tes, dengan menggunakan SPSS versi 25. Dari hasil pengolah data, menunjukkan Secara keseluruhan dampak Covid-19 terhadap kinerja keuangan perbankan syariah di Indonesia yang dilihat dari hasil tabel Uji Beda (Uji Paired Sample T-Test) rasio CAR, ROA, NPF dan FDR tidak signifikan menunjukan adanya perbedaan kinerja keuangan.
\end{abstract}

Kata Kunci : Kinerja Keuangan, CAR, ROA, NPF , FDR.

\begin{abstract}
Islamic banking in Indonesia faces a number of challenges amid the Covid-19 outbreak. During the current Covid 19 pandemic, Islamic banking will face several possible risks to financial performance. For this reason, it is necessary to conduct research to analyze the impact of Covid-19 on the financial performance of Islamic Banking by analyzing Financial Statements using financial ratios, namely the ratio of Return on Assets (ROA), Capital Adequacy Ratio (CAR), Non Performing Finance (NPF) and Financing Deposit. to Ratio (FDR). This research is a quantitative research with a descriptive approach. Data taken were 6 months (September 2019-February 2020) before and 6 months (April 2020-September 2020) after the announcement of the first case of Covid-19, namely on March 2, 2020. The data was processed with paired sample t-test, using SPSS version 25. From the results of the data processing, it shows that the overall impact of Covid 19 on the Financial Performance of Islamic Banking in Indonesia is seen from the results of the Table of Differences (Paired Sample TTest) CAR ratio, ROA, NPF and FDR do not show significant differences in financial performance.
\end{abstract}

Keyword : Financial Performance, CAR, ROA, NPF, FDR. 


\section{PENDAHULUAN}

Dalam masa pandemi, pemerintah Indonesia memutuskan untuk memperhatikan tiga sektor, yaitu kesehatan, sektor riil dan perbankan. Pandemi Covid-19 menjadi permasalahan bagi perbankan, karena bisa menghasilkan permasalahan di sektor riil atau dunia usaha yang berpotensi menimbulkan persoalan di sektor perbankan. Hal ini tentu saja bisa terjadi, dikarenakan sektor perbankan merupakan lembaga intermediasi atau perantara yang mendukung kebutuhan dana investasi bagi dunia usaha.

Perbankan syariah di Indoneisa menghadapi sejumlah tantangan di tengah wabah Covid-19. Menurut Pengamat Ekonomi Syariah yang juga pendiri Karim Consulting, Adiwarman Karim menyampaikan kondisi industri Perbankan Syariah bisa lebih dulu memburuk daripada industri bank konvensional.

Di masa pandemi Covid-19 saat ini, perbankan syariah akan menghadapi beberapa kemungkinan resiko, seperti resiko pembiayaan macet (NPF), resiko pasar dan resiko likuiditas. Oleh karenanya, resiko tersebut pada akhirnya akan memiliki dampak terhadap kinerja dan profitabilitas perbankan syariah. (Wahyudi, 2020).

Untuk itu perlu di lakukan penelitian untuk menganalisis dampak Covid-19 terhadap kinerja keuangan perbankan syariah dengan melakukan analisa laporan keuangan menggunakan rasio keuangan yaitu rasio Return $O n$ Asset (ROA), Capital Adequacy Ratio $(C A R)$, Non Performing Finance (NPF) dan Financing Deposit to Ratio (FDR).

\section{TINJAUAN PUSTAKA}

\section{Perbankan Syariah}

Perbankan syariah merupakan salah satu bagian dari kegiatan ekonomi. (Nurnasrina \& Putra, 2017). Bank berasal dari kata bangue (bahasa Perancis) dan dari kata banco (bahasa Italia) yang berarti peti/lemari atau bangku. Peti/ lemari dan bangku menjelaskan fungsi dasar dari bank komersial, yaitu : pertama, menyediakan tempat untuk menitipkan uang dengan aman (safe keeping function), kedua, menyediakan alat pembayaran untuk membeli barang dan jasa (transaction function) (Antonio. 2006). Sedangkan bank menurut Hasibuan (2011) adalah lembaga keuangan berarti bank adalah badan usaha yang kekayaan terutama dalam bentuk asset keuangan (financial asset) serta bermotifkan profit dan juga sosial.

Menurut Kasmir (2004) bank diartikan sebagai lembaga keuangan yang kegiatan usahanya adalah penghimpun dana dari masyarakat dan menyalurkan kembali dana tersebut ke masyarakat serta memberikan jasa-jasa bank lainnya. Sedangkan bank syariah adalah bank yang dalam kegiatannya beroperasi sesuai dalam prinsip-prinsip Islam. Bank ini kegiatan operasinya mengacu kepada yang telah ditetapkan oleh ketentuan-ketentuan al-Quran dan hadits. (Wibowo \& Widodo, 2005).

Bank syariah di Indonesia terbagi ke dalam dua bentuk, bentuk yang pertama yaitu Bank Umum Syariah (BUS) dan yang kedua Unit Usaha Syariah (UUS). BUS merupakan bentuk bank syariah yang kegiatannya memberikan jasa dalam lalu lintas pembayaran. Sedangkan UUS merupakan unit usaha syariah yang dimiliki oleh bank umum konvensional yang mempunyai fungsi sebagai kantor induk dari kantor atau unit yang melaksanakan kegiatan usaha berdasarkan prinsip Syariah.

\section{Kinerja Keuangan}

Menurut Zarkasyi (2008) Kinerja keuangan adalah merupakan sesuatu yang dihasilkan atau hasil kerja yang dicapai 
dari suatu perusahaan. Sedangkan Menurut Fahmi (2012) Kinerja keuangan dilakukan untuk menganalisis sejauh mana perusahaan telah melaksanakan dengan menggunakan aturan pelaksanaan keuangan secara baik dan benar. Seperti dengan membuat suatu lapaoran keuangan yang telah sesuai setandar dan ketentuan dalam SAK (Setandar Akutansi Keuangan) atau GAAP (General Acepted Accouting Principle).

Berdasarkan uaraian diatas, kinerja keuangan merupakan kondisi gambaran keuangan perbankan pada suatu periode tertentu baik itu aspek penghimpunan maupun penyaluran dana yang biasanya.

\section{Rasio Keuangan}

Menurut Kasmir (2012) Rasio keuangan merupakan kegiatan membandingkan angka-angka yang ada dalam laporan keuangan dengan cara membagi satu angka dengan angka lainya. Menurut Riyanto (2010) dalam mengadakan analisis rasio keuangan pada dasarnya dapat melakukanya dengan dua macam cara perbandingan yaitu:

1. Membandingkan rasio sekarang (present ratio) dengan rasio-rasio dari waktu-waktu yang lalu (ratio history) atau dengan rasio-rasio yang diperkirakan untuk waktu-waktu yang akan datang dari perusahaan yang sama. Dengan cara pembandingan ini akan dapat diketahui perubahanperubahan dari rasio tersebut dari tahun ke tahun. Kalau diketahui perubahan dari angka rasio tersebut maka dapatlah diambil kesimpulan mengenai tendensi atau kecenderungan keadaan keuangan serta hasil operasi perusahaan yang bersangkutan.

2. Membandingkan rasio-rasio dari suatu perusahaan dengan rasio-rasio semacam dari perusahaan lain yang sejenis atau industri (rasio industri/rasio standar) untuk waktu yang sama. Dengan cara ini akan dapat diketahui apakah perusahaan yang bersangkutan dalam aspek keuangan tertentu berada di atas ratarata industri, berada pada rata-rata atau terletak dibawah rata-rata industri.

Secara sederhana rasio disebut perbandingan angka, dari satu jumlah angka lainya dalam suatu perusahaan sejenis dengan menggunkan rasio-rasio yang sama untuk mengetahui keadaan keuangan serta hasil operasi perusahaan yang bersangkutan.

Dalam Surat Edaran Bank Indonesia (SEBI) No. 9 Tahun 2007 mengenai Sistem Penilain Tingkat Kesehatan Bank Umum Berdasarkan Prinsip Syariah, diatur lebih lanjut tentang rasio-rasio yang digunakan. Rasio-rasio keuangan tersebut dibedakan menjadi rasio utama, rasio penunjang dan rasio pengamatan (observed). Rasio utama merupkan rasio yang memiliki pengaruh kuat (high impact) terhadap Tingkat Kesehatan Bank. Sedangkan rasio penunjang adalah rasio yang berpengaruh secara langsung terhadap rasio utama dan rasio penunjang.

\section{CAR (Capital Adequacy Ratio)}

CAR merupakan indikator terhadap kemampuan bank untuk menutupi penurunan aktivanya sebagai akibat dari kerugian-kerugian bank yang disebabkan oleh aktiva yang berisiko dengan kecukupan modal yang dimilikinya (Dendawijaya, 2003). Semakin tinggi CAR maka semakin kuat kemampuan bank tersebut untuk menanggung risiko dari setiap pinjaman atau aktiva produktif yang berisiko. Atau dengan kata lain, maka semakin tinggi kecukupan modalnya untuk menanggung risiko pinjaman macetnya, sehingga kinerja bank semakin baik, dan dapat meningkatkan kepercayaan masyarakat terhadap bank yang bersangkutan yang berujung pada meningkatnya laba (ROA) (Ruslim, 
2012). Perhitungan CAR (Capital Adequacy Ratio) dirumuskan sebagai berikut:

$$
\mathrm{CAR}=\frac{\text { TOTAL MODAL }}{\text { TOTAL AMTR }} \mathrm{X} 100
$$

\section{ROA (Return On Assets)}

Menurut Dewi dan Prasetiono (2012), ROA dapat digunakan mengukur efektifitas perusahaan dalam menghasilkan keuntungan dengan memanfaatkan aktiva yang dimilikinya. Fungsinya adalah untuk melihat seberapa efektif perbankan dalam menggunakan asetnya dalam menghasilkan pendapatan. Semakin besar nilai ROA artinya semakin baik kemampuan perbankan dalam menghasilkan laba. Rumus untuk menghitung ROA yakni:

$$
\text { ROA } \frac{\text { LABA BERSIH SEBELUM PAJAK }}{\text { TOTAL ASET }} \text { X } 100
$$

\section{NPF (Non Performing Financing)}

NPF yang tinggi akan memperbesar biaya, sehingga berpotensi terhadap kerugian bank. Semakin tinggi rasio ini maka akan semakin buruk kualitas pinjaman bank yang menyebabkan jumlah pinjaman bermasalah semakin besar, dan oleh karena itu bank harus menanggung kerugian dalam kegiatan operasionalnya sehingga berpengaruh terhadap penurunan laba (ROA) yang diperoleh bank (Kasmir, 2004). Rumus untuk menghitung NPF yakni :

$$
\text { NPF } \frac{\text { PEMBIAYAAN BERMASALAH }}{\text { TOTAL PEMBIAYAAN }} \times 100
$$

\section{FDR (Financing to Deposit Ratio)}

FDR merupakan ukuran likuiditas yang mengukur besarnya dana yang ditempatkan dalam bentuk pinjaman yang berasal dari dana yang dikumpulkan oleh bank (terutama masyarakat). Apabila hasil pengukuran jauh berada di atas target dan limitnya, berarti tidak tertutup kemungkinan bank akan mengalami kesulitan likuiditas yang pada gilirannya akan menombulkan tekanan pada pendapatan bank (Kuncoro dan Suhardjono, 2002). Semakin tinggi FDR maka laba perusahaan semakin meningkat (dengan asumsi bank tersebut mampu menyalurkan pinjaman dengan efektif, sehingga jumlah pinjaman macetnya akan kecil). Rumus untuk menghitung FDR yakni:

$$
\mathrm{FDR}=\frac{\text { PEMBIAYAAN YANG DIBERIKAN }}{\text { DANA PIHAK KE TIGA }} \times 100
$$

\section{METODE PENELITIAN}

Penelitian ini adalah penelitian kuantitatif dengan pendekatan deskriptif. Pendekatan kuantitatif bertujuan untuk menguji teori, membangun fakta, menunjukkan hubungan antar variabel, memberikan deskripsi statistik, menaksir dan meramalkan hasilnya. (Tanzeh, 2011) Data dalam penelitian ini menggunakan data sekunder, yaitu data Statistik Perbankan Syariah yang dipublish Otoritas Jasa Keuangan (OJK). Data yang diambil adalah 6 Bulan (September 2019Februari 2020) sebelum dan 6 Bulan (April 2020-September 2020) setelah diumumkannya kasus pertama Covid-19 yaitu pada 2 Maret 2020 .

Penelitian ini merupakan menggunakan paired sample t-test. Paired sample t-test merupakan salah satu metode pengujian yang digunakan untuk mengkaji keefektifan perlakuan, ditandai adanya perbedaan rata-rata sebelum dan rata-rata sesudah diberikan perlakuan (Widiyanto, 2013) Pengujian ini digunakan untuk mengukur seberapa besar perbedaan kinerja keuangan perbankan syariah Indonesia, sebelum diumumkannya kasus Covid-19 yang terjadi pertama kali di Indonesia dan sesudah pengumuman. Pengolahan data pada penelitian ini menggunakan SPSS 
versi 25. Variabel-variabel pada penelitian ini, yang digunakan adalah :

1. Data sebelum kasus Covid-19 di umumkan secara nasional di Indonesia untuk petama kali . Data sebelum pegumuman nasional kasus Covid-19 di Indonesia untuk pertama kali ini meliputi data Laporan Keuangan Berupa CAR (Capital Adequacy Ratio),ROA (Return on Assets), NPF (Non Performing Financing) dan FDR (Financing to Deposit Ratio). Pada penelitian ini, data yang diambil sebelum kasus pertama virus corona sebanyak 6 .

2. Data sesudah pengumuman nasional kasus Covid-19 di Indonesia untuk pertama kali ini meliputi data CAR (Capital Adequacy Ratio), ROA (Return on Assets), NPF (Non Performing Financing) dan FDR
(Financing to Deposit Ratio). Pada penelitian ini, data yang diambil sesudah kasus pertama covid-19 sebanyak 6 .

3. Pengumuman kasus Covid-19 pertama nasional di Indonesia untuk pertama kali. Kasus Covid-19 pertama di Indonesia terhitung mulai 2 Maret 2020, yaitu pada saat diumumkan oleh pemerintah pertama kali terdapat orang Indonesia yang terkena Covid-19.

\section{HASIL DAN PEMBAHASAN}

\section{Statistik Deskriptif}

Berdasarkan data Tabel 1. menunjukan CAR berdasarkan peraturan Bank Indonesia bahwa standar CAR minimum adalah $8 \%$, maka nilai CAR dalam sampel periode ini masih berada pada kondisi yang baik karena masih berada diatas ketentuan minimum Bank Indonesia.

Tabel 1. Hasil Statistik Deskriptif

\begin{tabular}{|c|c|c|c|c|c|}
\hline \multicolumn{6}{|c|}{ Paired Samples Statistics } \\
\hline & & Mean & $\mathrm{N}$ & $\begin{array}{c}\text { Std. } \\
\text { Deviation } \\
\end{array}$ & $\begin{array}{c}\text { Std. Error } \\
\text { Mean }\end{array}$ \\
\hline Pair 1 & CAR_Sebelum_Covid19 & 20.5650 & 6 & .18663 & .07619 \\
\hline & CAR_Setelah_Pengumuman_Covid19 & 20.6667 & 6 & .33122 & .13522 \\
\hline
\end{tabular}
rata-rata $1.7 \%$. Dan ROA pada saat

\section{Tabel 2. Hasil Statistik Deskriptif}

\begin{tabular}{rlrrrr}
\hline \multicolumn{7}{c}{ Paired Samples Statistics } \\
\hline \multirow{2}{*}{ Pair 1 } & Mean & N & Std. Deviation & \multicolumn{2}{c}{ Std. Error Mean } \\
\cline { 2 - 6 } & ROA_Sebelum_Covid19 & 1.7400 & 6 & .10119 & .04131 \\
\hline
\end{tabular}

Sumber : Data Olahan (2020)

Dengan ini menunjukan bahwa data variabel ROA mengacu kepada ketentuan Bank Indonesia bahwa standar ROA berada pada > $1.5 \%$ adalah tergolong cukup baik, maka nilai ROA dalam sampel periode ini masih berada pada kondisi yang kurang baik karena masih berada di bawah ketentuan Bank Indonesia.

Berdasarkan Tabel 3. NPF pada saat sebelum Covid-19 memiliki nilai rata-rata $3.39 \%$. Dan NPF pada saat 
setelah pengumuman Covid-19 memiliki nilai rata-rata 3.33\%.

Tabel 3. Hasil Statistik Deskriptif

\begin{tabular}{llllrr}
\hline \multicolumn{7}{c}{ Paired Samples Statistics } \\
\hline \multirow{2}{*}{ Pair 1 } & Mean & N & Std. Deviation & \multicolumn{2}{c}{ Std. Error Mean } \\
\cline { 2 - 6 } & NPF_Sebelum_Covid19 & 3.3917 & 6 & .10187 & .04159 \\
\hline
\end{tabular}

Sumber : Data Olahan (2020)

Dengan ini menunjukan bahwa masih berada pada ketentuan Bank data variabel NPF mengacu kepada ketentuan Bank Indonesia bahwa standar NPF yang berada pada $2 \% \leq \mathrm{NPF}<5 \%$ adalah tergolong cukup baik, maka nilai NPF dalam sampel ini periode masih berada pada kondisi yang baik karena

\section{Indonesia.}

Berdasarkan Tabel 4. FDR pada saat sebelum covid 19 memiliki nilai ratarata $78.92 \%$. Dan FDR pada saat setelah pengumuman Covid-19 memiliki nilai rata-rata $79.36 \%$.

Tabel 4. Hasil Statistik Deskriptif

\begin{tabular}{|c|c|c|c|}
\hline \multicolumn{4}{|c|}{ Paired Samples Statistics } \\
\hline \multicolumn{4}{|c|}{ N Std. Deviation } \\
\hline \multirow{2}{*}{ Pair $1 \frac{\text { FDR_Sebelum_Covid19 }}{\text { FDR Setelah Penoumuman Covid19 }}$} & 78.9250 & 1.67164 & .68245 \\
\hline & 79.3683 & 1.40478 & .57350 \\
\hline \multicolumn{4}{|c|}{ Sumber : Data Olahan (2020) } \\
\hline $\begin{array}{l}\text { Dengan ini menunjukan bah } \\
\text { data variabel FDR mengacu kepa } \\
\text { ketentuan Bank Indonesia bahwa stand } \\
\text { FDR yang baik adalah maksimum } 110 \\
\text { maka nilai FDR dalam sampel periode } \\
\text { masih berada pada kondisi yang ba } \\
\text { karena masih berada dibawah bat } \\
\text { maksimum ketentuan Bank Indonesia. }\end{array}$ & $\begin{array}{l}\text { pad } \\
\text { per } \\
\text { Co } \\
\text { Co } \\
\text { pen } \\
\text { rat } \\
\text { den }\end{array}$ & $\begin{array}{l}\text { CAR Berd } \\
\text { da Tabel } 5 . \\
\text { rbedaan sebesai } \\
\text { ovid-19 dan } \\
\text { ovid-19 deng } \\
\text { ngumuman Cov } \\
\text { ta-rata nilai CA } \\
\text { ngan nilai thitun }\end{array}$ & $\begin{array}{l}\text { kan hasil penelitian } \\
\text { enunjukan adanya } \\
1 \% \text { pada sebelum } \\
\text { lah pengumuman } \\
\text { CAR setelah } \\
9 \text { lebih tinggi dari } \\
\text { sebelum Covid-19 } \\
\text { ang negatif. }\end{array}$ \\
\hline
\end{tabular}

Uji Beda (Uji Paired Sample T-Test)

Tabel 5. Hasil Statistik Deskriptif

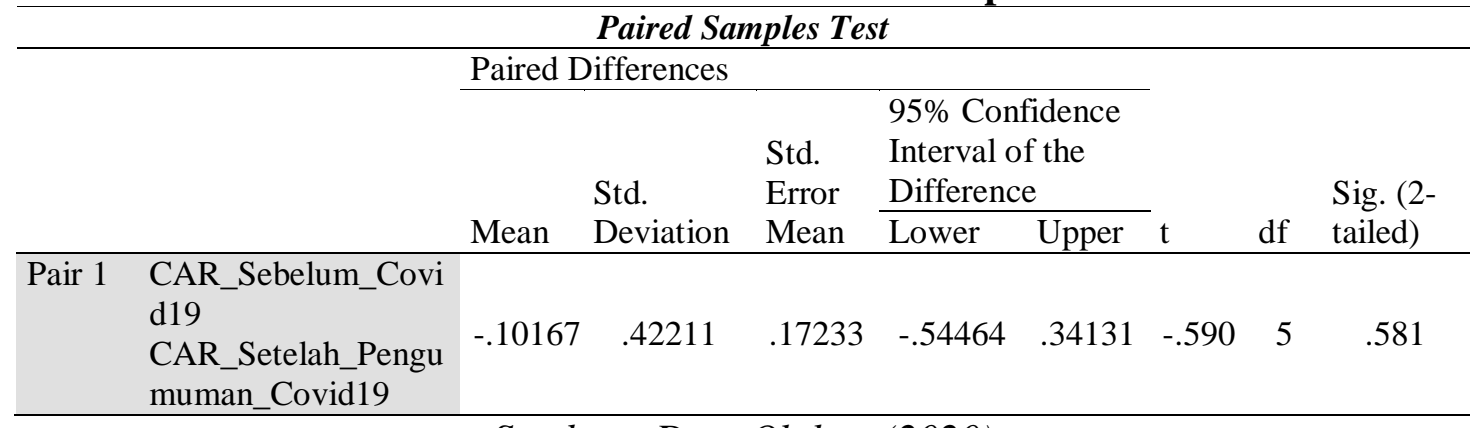

Sumber : Data Olahan (2020)

Dengan ini menunjukan bahwa data variabel CAR pada Perbankan Syariah di Indonesia tidak berdampak oleh Covid-19.
Pada Tabel 6. ROA Berdasarkan hasil penelitian menunjukan adanya perbedaan sebesar $0,3 \%$ pada sebelum covid 19 dan setelah pengumuman 
Covid-19 dengan ROA sebelum Covid- setelah pengumuman Covid-19 dengan 19 lebih tinggi dari rata-rata nilai ROA nilai thitung yang positif.

Tabel 6. Hasil Statistik Deskriptif Paired Samples Test

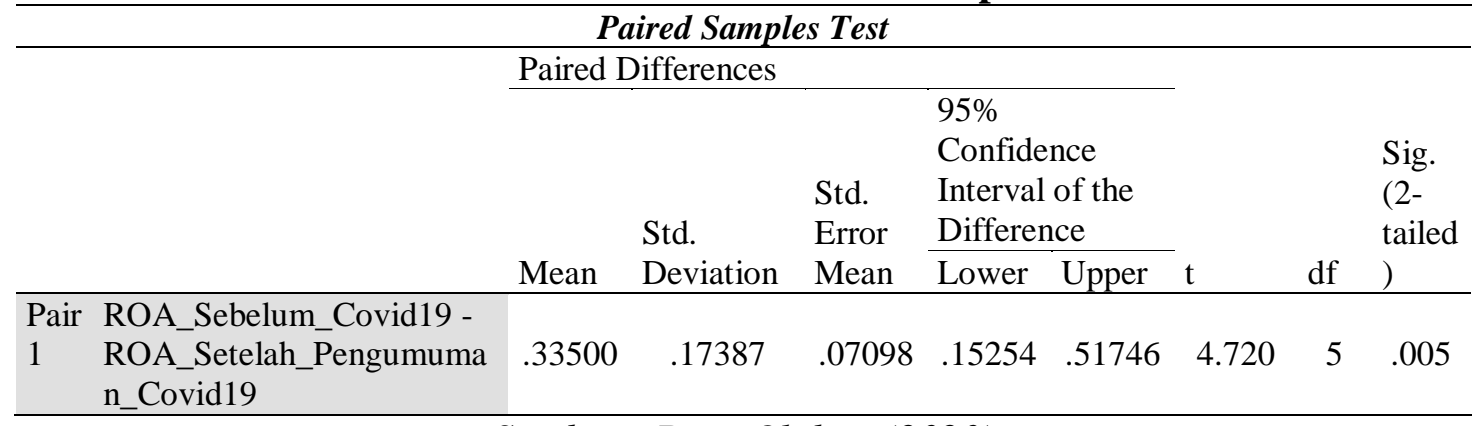

Sumber : Data Olahan (2020)

Dengan ini menunjukan bahwa perbedaan sebesar $0,06 \%$ pada sebelum data variabel CAR pada Perbankan Covid-19 dan setelah pengumuman Syariah di Indonesia berdampak oleh Covid-19 dengan NPF sebelum Covid-19 Covid-19 namun tidak terlalu signifikan. lebih tinggi dari rata-rata nilai NPF Pada Tabel 7. NPF Berdasarkan setelah pengumuman Covid-19 dengan hasil penelitian menunjukan adanya nilai thitung yang positif.

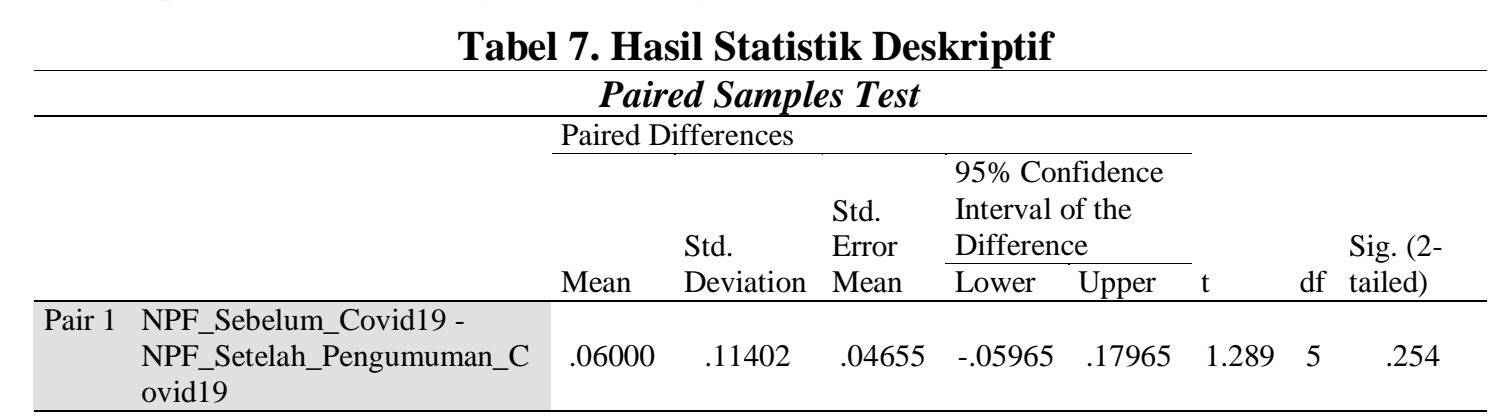
Sumber : Data Olahan (2020)

Dengan ini menunjukan bahwa perbedaan sebesar $0.44 \%$ pada sebelum data variabel CAR pada Perbankan Covid-19 dan setelah pengumuman Syariah di Indonesia berdampak oleh Covid-19 dengan FDR pengumuman Covid-19 namun tidak terlalu signifikan. Covid-19 lebih tinggi dari rata-rata nilai Pada Tabel 8. FDR Berdasarkan FDR sebelum Covid-19 dengan nilai t hasil penelitian menunjukan adanya hitung yang positif.

Tabel 8. Hasil Statistik Deskriptif

\begin{tabular}{|c|c|c|c|c|c|c|c|c|c|}
\hline \multicolumn{10}{|c|}{ Paired Samples Test } \\
\hline & & \multicolumn{5}{|c|}{ Paired Differences } & \multirow[b]{3}{*}{$\mathrm{t}$} & \multirow[b]{3}{*}{$\mathrm{df}$} & \multirow{3}{*}{$\begin{array}{l}\text { Sig. } \\
(2- \\
\text { tailed })\end{array}$} \\
\hline & & \multirow[b]{2}{*}{ Mean } & \multirow{2}{*}{$\begin{array}{l}\text { Std. } \\
\text { Deviatio } \\
\mathrm{n}\end{array}$} & \multirow{2}{*}{$\begin{array}{l}\text { Std. } \\
\text { Error } \\
\text { Mean }\end{array}$} & \multicolumn{2}{|c|}{$\begin{array}{l}95 \% \text { Confidence } \\
\text { Interval of the } \\
\text { Difference }\end{array}$} & & & \\
\hline & & & & & Lower & Upper & & & \\
\hline Pair 1 & $\begin{array}{l}\text { FDR_Sebelum_Covid19 } \\
\text { - } \\
\text { FDR_Setelah_Pengumu } \\
\text { man_Covid19 }\end{array}$ & -.44333 & 2.09692 & .85606 & -2.64391 & 1.75725 & -.518 & 5 & .627 \\
\hline
\end{tabular}

Sumber : Data Olahan (2020) 
Dengan ini menunjukan bahwa data variabel CAR pada Perbankan Syariah di Indonesia berdampak oleh Covid-19 namun tidak terlalu signifikan.

\section{KESIMPULAN}

Berdasarkan pengolahan data dan hasil analisis data yang mengacu pada masalah dan tujuan penelitian secara deksriptif dan statistik, maka dapat diperoleh kesimpulan bahwa Secara keseluruhan dampak Covid-19 terhadap Kinerja Keuangan Perbankan Syariah di Indonesia yang dilihat dari hasil tabel $\mathrm{Uji}$ Beda (Uji Paired Sample T-Test) rasio CAR, ROA, NPF dan FDR tidak signifikan menunjukan adanya perbedaan kinerja keuangan. Artinya perbankan syariah di Indonesia masih mampu bertahan ditengah masa pandemi hanya saja jika untuk kedepannya Covid-19 masih belum menunjukkan tanda-tanda penurunan maka saran dari penulis agar perbankan syariah di Indonesia salah satunya melakukan pembiayaanpembiayaan (FDR) di sektor-sektor baru yang langsung berkaitan dengan wabah pandemi Covid-19.

\section{DAFTAR PUSTAKA}

Antonio, M. Syafi'i. 2006. Dasar- Dasar Manajemen Bank Syariah. Pustaka Alfabeta. Jakarta.

Dendawijaya, Lukman. 2013. Manajemen Perbankan. Ghalia Indonesia. Jakarta.

Dewi, Kartika Shintia dan Prasetiono, P. 2012. Analisis Pengaruh ROA, NPM, DER, dan Size Terhadap Praktik Perataan Laba (Studi kasus pada perusahaan manufaktur yang terdaftar di Bursa Efek Indonesia periode 2007-2010), Journal of Management, 1(4), 172-180.

Fahmi, Irham. 2012. Analisis Kinerja Keuangan. Alfabeta. Bandung.
Hasibuan, Melayu. 2011. Dasar-dasar Perbankan. PT Bumi Aksara. Jakarta.

Kasmir. 2004. Manajemen Perbankan. PT Raja Grafindo Persada. Jakarta.

Kasmir. 2012. Pemasaran Bank. Prenada Media. Jakarta .

Kuncoro, Mudrajad dan Suhardjono. 2002. Manajemen Perbankan Teori dan Aplikasinya. BPFE. Yogyakarta.

Nurnasrina, dan Putra, Adiyes. 2017. Kegiatan Usaha Bank Syariah. Kalimedia. Yogyakarta.

Riyanto, Bambang. 2010. Dasar-Dasar Pembelanjaan Perusahaan (Edisi 4). BPFE. Yogyakarta.

Ruslim. 2012. Analisis Pengaruh Capital Adequancy Ratio (CAR), Non Performing Loan (NPL), dan Loan to Deposit Ratio (LDR) Terhadap Return On Asset (ROA) Pada Bank Umum Syariah Yang Terdaftar Di Bank Indonesia. Jurnal Perbankan Syariah, 1(1).

Sekaran, Umar \& Bougie, Roger. 2017. Metode Penelitian untuk Bisnis, Edisi 6. Salemba Empat. Jakarta Selatan.

Tanzeh, Ahmad. 2011. Metodologi Penelitian Praktis. Teras. Yogyakarta.

Wahyudi, Rofiul. 2020. Analisis Pengaruh CAR, NPF, FDR, BOPO dan Inflasi terhadap Profitabilitas Perbankan Syariah di Indonesia: Studi Masa Pandemi Covid-19. Journal of Walisongo, 12(1). 13-24.

Wibowo, Edy dan Widodo, Untung Hendy. 2005 Mengapa Memilih Bank Syariah? Cet. I. Ghalia Indonesia. Bogor.

Widiyanto, Mikha Agus. 2013. Statistika Terapan. Konsep dan Aplikasi 
2021, Jurnal Tabarru' : Islamic Banking and Finance 4 (1) : 37 - 45

dalam Penelitian Bidang

Pendidikan, Psikologi dan Ilmu Sosial Lainnya. PT Elex Media Komputindo. Jakarta.

Zarkasyi, Moh Wahyudin. 2008. Good Corporate Governance, Pada Badan Usaha Manufaktur, Perbankan, dan Jasa Keuangan Lainnya. Alfabeta. Bandung. 